\title{
Resistensi Tradisi Terhadap Modernitas
}

\author{
Abdul Jalil ${ }^{1}$, Siti Aminah ${ }^{2}$ \\ ${ }^{1}$ Antropologi Fakultas Imu Budaya Universitas Haluoleo \\ abduljalil.uho@gmail.com \\ ${ }^{2}$ Pengembangan Masyarakat Islam, FDK UIN Sunan Kalijaga Yogyakarta
}

\begin{abstract}
This paper discussess people understanding on the concept of tradition and modernity, in terms of material and immaterial tradition. This article has been inspired by Michael Rowland's idea on the 'Inconsistent Temporalities in a Nation State' published in Daniel Miller book 'Worlds Apart Modernity Through The Prish of The Local.' This paper aims to see the relationship and negotiation between the concept of tradition and modernity, as well examine the post tradition phase. The method of analysis being used in this article is descriptive analysis. The results of the analysis suggests that the resistance of tradition to modernity had led to the emergence of postmodernity.
\end{abstract}

Keywords: Resistance, Tradition, Modernity, Postmodernity.

\begin{abstract}
Abstrak
Tulisan ini mendiskusikan pemahaman masyarakat mengenai tradisi dan modernitas, baik yang bersifat materi maupun immateri. Selain itu, tulisan ini juga terinspirasi dari artikel Michael Rowland tentang Inconsistent Temporalities in a Nation State dalam buku Daniel Miller Worlds Apart Modernity Through The Prish of The Local. Tulisan ini bertujuan melihat lebih jauh relasi bahkan negosiasi antara tradisi dan modernitas, atau ada fase setelah tradisi, sehingga menjadi hubungan tradisi-modern-postmodern. Metode yang digunakan dalam analisis tulisan ini adalah deskriptif analitis. Hasil dari analisis ini menemukan bahwa fenomena resistensi tradisi terhadap modernitas, ternyata menghadirkan dunia baru yang disebut postmodernitas.
\end{abstract}

Kata Kunci: Resistensi, Tradisi, Modernitas, Postmodernitas.

\section{Pendahuluan}

Istilah "resistensi" sangat menarik untuk didiskusikan, terutama dalam teori-teori antropologi masa kini. Tema resistensi menarik karena berada pada tengah-tengah antara pemikiran Marx dalam antropologi dan pemikiran antropologi simbolik yang berorientasi pada kebudayaan atau yang memiliki sensitivitas budaya. Pemikiran Marx dalam antropologi, sekilas konyol karena tokoh ini biasa dikenal sebagai pemikir politik radikal, filosof, dan hantu ideologi. Lebih dari itu, dalam bukunya Karl
Marx, Anthropologist karya Thomas Patterson sebagaimana yang telah dijelaskan Dede Mulyanto dalam meresensi buku tersebut, bahwa Antropologi Marx terletak pada tiga pilar utama, yakni pemahaman manusia sebagai organisme, manusia sebagai mahluk sosial, dan praksis sebagai hakikat masyarakat manusia (Dede Mulyanto, 2016: 78). Sementara kehadiran resistensi tidak lain sebagai jalan rekonsiliasi antara pemikiran keduanya, di samping analisis resistensi juga berkaitan dengan anropologi feminis. Misalnya pernyataan Geertz dalam Resistensi: Arus Balik Fungsional?, ia 
menyatakan bahwa antropologi tampaknya harus berada pada posisi di tengah-tengah karena posisinya yang tidak selalu pada ranah pemikiran teoritis, melainkan lapangan empiris yang langsung bersumber dari warga masyarakat yang nyata. Kecenderungan jalan tengah tersebut terekspresi melalui suatu perkembangan penting dalam analisis teoritis antropolog yang membangun mode etnografi baru yaitu etnografi yang bertema resistensi terhadap struktur ketidaksetaraan (ketidakadilan) atau penindasan (oppression), apakah yang terkait dengan perbedaan kelas, gender, atau etnisitas (Saifudin, 2005: 395).

Resistensi juga sering diistilahkan dengan perlawanan, modern berlawanan dengan postmodern, menekankan pada pandangan dunia yang holistik dan koheren. Apabila posmodernisme merupakan jalan tengah yang dapat diterima, maka isu materi yang sangat menonjol dalam pemikiran Marx banyak tercermin pada kajian-kajian para antropolog yang menganalisis masalah kebudayaan lokal, translokal, dan global pada masa kini. James Scoot mencatat bahwa gejala resisteni yang sekalipun memusatkan diri pada kasus-kasus lokal untuk membicarakan hubungan intralokal dan ekstralokal (Saifudin, 2005: 422).

Anna L. Tsing (1998) menggambarkan lebih eksplisit dibanding Scoot dan Abu Lughood tentang hubungan lokal, regional, dan Negara. Ia menegaskan bahwa senantiasa terjadi hubungan dialektika dalam bentuk akomodasi dan resistensi antara lokal dan kekuasaan yang lebih tinggi, yakni negara dengan berbagai tingkat kekuasaannya. Dengan kata lain, terjadi dinamika yang lebih kompleks dalam hubungan antara kebudayaan di dunia dalam konteks globalisasi, tentu bukan sesuatu yang sederhana dan akomodasi kebudayaan yang semata-mata terkait dengan material world dan materi sebagai kekuatan pendorong (material trajectoris) bagi terjadinya perubahan kebudayaan sebagaimana diasumsikan dalam pandangan materialisme kebudayaan (Saifudi, 2995: 396).
Tulisan ini terinspirasi dari artikel Michael Rowland tentang Inconsistent Temporalities In A Nation State dalam bukunya Daniel Miller yang berjudul Worlds Apart Modernity Through The Prish of The Local. Di dalam artikel ini, Rowland memang lebih banyak menyinggung antara tradisi dan modernitas. Keduanya tidak dapat disatukan karena sudah lain orientasi dan kepentingannya. Modern mengklaim dirinya sebagai representasi the other dalam sejarah persatuan nasional yang diidentikkan dengan pemberian kebebasan individu untuk mengakses segala sesuatu yang dianggap penting dan cenderung kontemporer. Sementara tradisi merupakan representasi generasi atau masa klasik yang bersifat statis, cenderung normatif konservatif, mengedepankan serta mempertahankan nilainilai luhur (Rowlands, 1995-23-24). Tradisi adalah indegeneous yang belum ternodai oleh gelombang globalisasi. Kemudian Rowland juga menyinggung tentang seberapa kuatkah tradisi utuk memertahankan keorisinilitasnya dalam konteks Negara? Bagaimana peran Negara dalam pembentukan national culture?

Tulisan ini menjadi pembanding dari apa yang telah ditemukan oleh Rowlands, yaitu kalau tradisi dan modernitas masing-masing tidak bisa disatukan karena keduanya berbeda orientasi, penulis justru melihat sebuah fenomena, yang awal mulanya sebagai proses perlawanan, namun hasil dari perlawanan itu menjadikan dunia baru yakni posmodernitas. Dengan demikian, istilah tradisional dan modernitas tidak bisa hidup sendiri-sendiri, terkadang yang nampak tradisi, ternyata justru modern. Sebaliknya yang kelihatanya modern, justru ternyata masih tradisi. Sebuah ungkapan yang bisa penulis kategorikan sebagai batas-batas yang tipis untuk menyebut sesuatu sebagai representasi dari tradisi (klasik) atau modern, misalnya ada ungkapan baliho di Kota Kendari berupa "berfikir global bertindak lokal”. Menurut penulis, hal inilah yang disebut anti tesis antara apakah klasik/lokal/tradisi atau sebuah ungkapan 
yang modern, masa kini, dan global. Meskipun dalam perspektif Rowland kedua istilah antara tradisi dan modernitas memang tidak dapat disatukan, namun pada saat yang sama Rowlan memberikan batas-batas, mana yang dikategorikan sebagai tradisi dan modern. Untuk memberikan predikat semacam ini, penulis menggunakan istilah postmodernitas karena seakan-akan tradisi melakukan perlawanan terhadap modernitas namun dari pengintegrasian antara klasik dan masa kini menuju penyebutan yang baru, yaitu postmodernitas. Hal inilah yang akan dikupas dalam paper ini.

\section{Kajian Pustaka}

\section{Tradisi}

Tradisi adalah kebiasaan yang diwariskan dari satu generasi ke generasi berikutnya secara turun temurun. Dalam hal ini, penulis terbayang atas konsep bentuk transportasi bentor/becak motor, yang kemudian penulis simpulkan sementara itulah bentuk hubungan baik antara tradisi dan modernitas. Tradisi atau tradisional dari bentuk becak itu sendiri, sementara motor mewakili modernitas, maka ketika telah menjadi bentor/becak motor, penulis asumsikan sebagai wujud postmodernitas, meskipun sebanarnya konsep ini sangat luas tidak hanya sebuah ilustrasi bentor semata, melainkan dapat dianalogkan pada konsep-konsep lain. Dari sisnilah muncul gagasan penulis, terjadi sebuah perlawanan antara tradisi dengan modernitas atau sesuatu yang beda antara tradisi dan modernitas. Jika keduanya mencoba diharmoniskan, maka muncul dunia baru, yakni postmodernitas, yang bukan tradisi, juga bukan modernitas. Sebuah perkawinan antara keduanya. Namun pada tulisan ini, penulis hanya sebuah penelitian yang cenderung pada ranah pemikiran dan konsep, bukan sebuah penelitian lapangan.

Term "tradisi" disini bukan berarti kebiasaan atau rutinitas yang muaranya pada aspek ritual, namun sebuah konsep yang dapat dimaknai sebagai bentuk masa lalu, yang klasik dan bukan yang berkembang saat ini dan bukan yang kontekstual, melainkan sebuah ungkapan yang merujuk pada masa bukan modern (masa kini). Sebagaimana jika dirumuskan dalam operasional akan identik dengan kebiasaan, misalnya dalam Kamus Besar Bahasa Indonesia (KBBI), tradisi adalah adat kebiasaan turun temururn (dari nenek moyang) yang masih dijalankan di masyarakat; atau penilaian atau anggapan bahwa cara-cara yang telah ada merupakan yang paling baik dan benar resistensi(kbbi.co.id).

\section{Resistensi}

Resisten/resistensi sebagaimana penjelasan Adnani dalam tulisannya yang berjudul Resistensi Perempuan Terhadap TradisiTradisi di Pesantren-Analisis Wacana Kritis Terhadap Novel Perempuan Berkalung Sorban didefinisikan bahwa pengertian resistensi (resistance) menunjukkan pada posisi sebuah sikap untuk berperilaku bertahan, berusaha melawan, menentang, atau upaya oposisi. Pada umumnya, sikap ini tidak berdasarkan atau merujuk pada paham yang jelas (Adnani, 2016: 3). Resistensi sebuah konsep yang dipahami sebagai bentuk perlawanan atas sesuatu terhadap sesuatu yang lain. Ketika terminologi Resistensi Tradisi Terhadap Modernitas, berarti sebuah perlawanan dari tradisi atas modernitas. Lebih lanjut dalam artikel tersebut, Kamlia mencoba memberikan ruang yang lebih bagi perempuan, bahkan sosok perempuan tidak hanya melawan atas hegemoni dunia pesantren sebagaimana peran perempuan selama ini, yaitu sebagai sosok yang termarginalkan, subordinasi bagi laki-laki, terbelakang melainkan sebagai sosok yang cerdas, berani dan kritis sebagaimana dalam novel Perempuan Berkalung Sorban.

Pemaknaan term resistensi juga dapat merujuk pada sebuah tulisan dari Abdurrachman May tentang Resistensi Aliran Salafi Terhadap Islam Tradisional Di 
Lombok Barat, Nusa Tenggara Barat. Artikel ini melihat adanya perlawanan Salafisme terhadap Islam Tradisional di Barat Lombok, Nusa Tenggara Barat yang dimotivasi oleh aspek penelitian, antara lain: pengulangan kekerasan sektarian religius di Pulau Lombok; dominasi rezim Islam Tradisional (Istra) dalam berbagai sosial. Penelitian ini bertujuan mengidentifikasi bentuk, faktor, serta makna dan dampak perlawanan Salafisme terhadap Islam Tradisional di Lombok Barat. Faktor resistensi Salafisme terhadap Islam tradisional dipicu oleh pertama, perbedaan paradigma dalam penafsiran ayat-ayat Alquran; kedua, klaim sebagai Ahlussunnah wal Jamaah; ketiga, pertentangan terhadap praktik-praktik agama sinkretistik dari Islam tradisional; keempat kebuntuan komunikasi. Kesimpulan dari penelitian ini memberikan gambaran tentang dinamika praktik keagamaan Islam berbasiskan sinkretisme di Lombok Barat, Nusa Tenggara Barat. Sementara ketahanan Salafi muncul dalam bentuk penolakan terhadap praktik agama Islam tradisional yang terkait pemberantasan wacana takhayul, bidah / bidaah dan khurafat. Keberadaan Tuan Guru sebagai seorang model peran dari Islam Tradisional menjadi objek kritik terhadap salafisme (Abdurrachman May, 2013: 44-48).

\section{Modernitas}

Di dalam term modernitas, penulis merujuk istilah Anthony Giddens dari karya aslinya The Conseguences of Modernity yang kemudian diterjemahkan dalam bahasa Indonesia dengan judul Tumbal Modernitas Ambruknya Pilar-pilar Keimanan, tulisan ini sebagai bentuk konsekuensi dari modernitas yang kemudian beresiko merapuhkan bangunan keimanan seseorang, selain itu dunia globalisasi juga sering dibarengkan dengan modernitas. Resiko yang dimaksd adalah sebuah ungkapan kondisi masyarakat dewasa ini atas beberapa ancaman eksternal yakni dunia globalisasi dan modernitas itu sendiri.
Dengan kata lain, Modernisme dengan segala kejeniusan imanentalnya telah berhasil meruntuhkan tiang-tiang peradaban tradisionalisme. Nilai-nilai luhur yang arif dan bijak pada tradisi telah hanyut, nilai etnik antar satu suku dengan suku lain tidak harmonis karena masing-masing saling ego karena telah dipengaruhi modernitas. Hal ini bisa dilihat dalam pawai budaya, setiap etnis mampu menampilkan keunggulan budayanya, namun pada saat yang sama justru setelah pawai budaya tersebut harus diapresiasi, maka beberapa suku dapat dipastikan akan tersinggung karena kenapa budaya mereka yang mendapat juara, apa kelebihannya, dan yang lain. Ilustrasi pawai budaya merupakan salah satu nilai-nilai luhur budaya ternodai setelah segala sesuatunya harus dikompetisikan. Mengapa harus dikompetisikan karena modernisme hadir. Dengan demikian, tulisan ini sangat mengilhami apa yang penulis kerjakan terkait isu tentang sebuah resistensi tradisional terhadap modernitas yang kemudian melahirkan dunia baru yang disebut postmodernisme.

\section{Postmodern/Postmodernitas}

Postmodern/postmodernitas/postmodernisme /postmo sebuah ungkapan yang berbeda dari modern. Secara bahasa, post berarti suatu keadaan yang sudah lewat, lepas, terpisah, terputus atau beyond. Meskipun kemudian dalam pengantar buku Teori Sosial Postmodern karya George Ritzer yang sudah diterjemahkan oleh Muhammad Taufik menyebutkan meskipun arti secara bahasa post seperti tersebut, namun secara makna bukanlah begitu. misalnya, apakah postmodernisme berarti sudah melewati batas modernisasi, atau kata laib, tidak modern lagi?. Dalam buku ini, pemikiran atau konsep yang tiba-tiba booming pasti mempunyai sebab yang mendahuluinya. Perlu digali secara argumentatif-filosofis.

Postmodernisme adalah bagian inheren/ turunan dari modernitas, meskipun kehadiran postmo sebagai bentuk anti atau teriakan nada protes atas modernitas. Buku ini 
menyajikan wacana awal bagi kritik ide-ide pokok dan pemikir-pemikir dalam perspektif postmo. Dengan kata lain, buku ini menggunakan pemahaman modern atas teori sosial postmodern, artinya bagaimana memandang dunia sosial dengan menggunakan keduanya bukan pada sudut pandang yang sempit (George Ritzer, 2005: viii). Meskipun pada akhirnya, diskursus terkait postmo tidak akan ada habisnya, masih mengandung pro dan kontra.

\section{Metode}

Penelitian ini merupakan bentuk dari sebuah pemikiran atau konsep tentang tradisi dan modernitas. Bahkan setelah ditelusuri terjadi resistensi dari tradisi terhadap modern itas. Penelitian ini bersifat deskriptif analisis dari konsep "tradisi dan modernitas" bahkan bisa jadi postmodernitas”, yang bertujuan menggambarkan bagaimana konsep tradisi dengan modern untuk kemudian dianalisis. Selain itu, penulis terinspirasi dari artikel Michael Rowland yang menyatakan bahwa antara tradisi dan modernitas tidak dapat disatukan, keduanya berbeda orientasi.

Adapun data penelitian yang digunakan bisa dari data primer dan sekunder. Data primernya melalui beberapa konsep tentang tradisi dan modernitas bahkan postmodernitas yang menurut penulis sebagai referensi penting, sementara data sekunder bersumber dari beberapa referensi lain terkait dengan makna dan operasional konsep tradisi dan modernitas, misalnya: sumber pustaka, baik elektronik (internet) maupun cetak: buku, jurnal, dan hasil penelitian.

\section{Hasil dan Pembahasan}

Dalam bahasan ini, perlu didefinisikan bahwa modernitas selalu menunjuk pada bentuk-bentuk sosial atau organisasi yang muncul di Eropa pada sekitar abad ke-17 ke depan yang kemudian berhasil menjadikan dunia dalam pengaruhnya. Definisi ini menghubungkan modernitas dengan periode waktu, atau lokasi geografis. Di penghujung abad ke-20, modernitas diperdebatkan banyak pihak. Sementara itu ide "posmodernitas" yang menunjuk pada perubahan epistemologi dipopulerkan oleh Jean Francois Lyotard. Institusi-institusi sosial modern termasuk berbagai keunikannya sangat berbeda dengan semua bentuk aturan tradisional (Giddens, 2001: 78).

Lyotard mengemukakan bahwa suatu tema utama postmodernisme adalah kemerosotan kekuasaan legitimasi "metanaratif" sebagai ciri distingtif kebudayaan postmodern. Metanaratif mengacu pada teori-teori fondasional, yaitu pengetahuan, moralitas, estetik dan kisah-kisah besar kemajuan sosial yang sentral bagi legitimasi pengetahuan, kebudayaan, dan institusi modern. Bagi Lyotard, bentuk asumsi pengetahuan sosial dalam kebudayaan postmodern adalah ilmuilmu mengenai manusia dapat menjadi kontrol sosial birokratis. Pengetahuan dalam konteks ini meninggalkan standar-standar absolut, kategori-kategori universal, dan teori-teori besar. Sementara para penganut postmodern lebih menyukai tipe-tipe kajian sosial yang bersifat lokal secara historis kontekstual dan pragmatik.

Nilai pengetahuan postmodern mendorong agar kita lebih cermat dan awas, serta toleran terhadap perbedaan-perbedaan sosial, ambiguitas, dan konflik. Bagi Lyotard, kita tidak bisa bicara self atau politik, dengan demikian, tidak ada center. Tidak ada landasan keteraturan, koheren, dan tujuan yang menyatukan. Postmodernitas ditandai oleh lenyapnya kepastian dan "sudut pandang ketentuan Tuhan"dalam pengetahuan, hilangnya prinsip pengaturan masyarakat yang bersifat sentral dan standar penyatuan dari Cultural Excellent atau moralitas, dan kemerosotan keyakinan yang koheren mengenai self (Saifudin, 2005: 381382). Bentuk kehidupan yang terbawa modernitas telah menjauhkan dari semua bentuk aturan tradisional.

Lain halnya dalam perspektif Feathostone, dalam alam makro selalu mengalami 
kemungkinan-kemungkinan perubahan, diantaranya: modifikasi “ sign”, sesuatu yang secara empiris sudah tidak layak untuk dikonsumsi, namun karena telah dimodifikasi dengan menjadi suatu produk antik meskipun tuadan cenderung dikelompokkan sebagai sesuatu yang klasik, tentu akan menjadi nilai lebih yang banyak digandrungi atau diminati oleh sebagian besar masyarakat. Ilustrasi pernyataan ini sebenarnya hendak menjelaskan proses dari tradisional kemudian disusul dengan modernisasi dan terakhir modifikasi antara sesuatu yang dikategorikan sebagai kategori tradisional dengan yang dikategorikan sebagai modrnisasi, itulah yang kemudian disebut postmodernisasi.

\section{Tradisional, Modernisasi, Postmodernisasi}

Salah satu sifat modern adalah selalu mengalami migrasi. Modern yang kemudian mewujudkan postmodernisme (yang dianggap sebagai kritik atas narasi-narasi besar) bukanlah sesuatu yang kontinuitas. Post-modernitas (kondisi globalisasi teknologi, informasi, dan merosotnya negara/bangsa, tatanan dunia baru) tidak lain adalah varian tersendiri bukan lagi sebagai kelanjutan dari tradisional dan modernisasi, melainkan kombinasi antara sesuatu yang dianggap klasik dengan kontemporer. Hanya saja dalam ilustrasi contoh benda, sangat wajar sama antara tradisional dengan postmodern, yang membedakannya adalah pada aspek makna yang terkandung didalamnya. Sementara konsep Ngango tentang Modern adalah ketika seseorang mampu mengindividualkan tradisi. Pernyataan ini dapat dilihat ketika dia pada awal 1950-an mengawali bisnis dari penjualan surat kabar di Nigeria dan kemudian mencari lisensi atau membuat ijin agar dapat mengimpor majalah ke Britain. Dari sinilah, ia melihat adanya peluang bisnis transportasi. Akhirnya mencoba mendistribusikan minyak di Camerun Barat sampai kemudian diklaim sebagai orang top ketiga dari empat pengusaha atau pemilik modal di Kamerun. Bagi dia, sebagaimana prinsip Fru Ndi-tokoh politik yang mempunyai sebuah gerakan untuk menyatukan antara daerah jajahan Inggris dan Prancis demi mengembalikan Negara sebagai Negara merdeka atau Negara federal yang bebas mengelolanya sendiri, padahal Afrika tidak pernah lepas dari jajahan Inggris dan Prancis, sementara konsep tawaran Fru Ndi yang kemudian didukung oleh Ngango akan mencoba membongkar paradigma yang selama ini sudah melekat pada sebuah kemapanan yang disebut Negara Afrika harus dijajah sebuah kemutlakan adanya.

Dari sini dapat dipahami bahwa Ngango mencoba menawrkan bahwa prinsip modernitas atau tradisi bukan berarti sesuatu yang "mengglobal” atau "melokal”, sementara dirinya dalam posisi yang tidak pernah merasakan sebuah kebebasan eksistensi dirinya dalam mitra dengan lingkungan lain, artinya paradigma Ngango tentang tradisi jauh lebih maju ke depan. Misalnya, Ngango selalu berada pada garis rakyat atau bersama-sama menggunakan kekuatan mayoritas penduduk untuk melakukan resistensi terhadap sebuah rezim berkuasa, apalagi yang otoriter. Tradisi bagi Ngango adalah sebuah kekuatan individu untuk melakukan gerakan, padahal dalam konteks ini, yang mereka hadapi adalah mitra-mitra para pengusaha yang telah menginvestasikan melalui politik organisasi tradisional, keuntungan bisnis dapat diperoleh. Dari perusahaan kecil, Ngango kemudian tertarik untuk melakukan usaha dalam bidang makanan, perumahan dan sebagainya sebagai aset-aset produktif dan lebih mudah diperoleh dibanding hal-hal yang bersifat indegeneous atau asli.

Postmodernisme atau yang sering dibaca postmo, secara bahasa berarti suatu keadaan yang sudah lewat, lepas, terpisah, terputus atau beyond, tetapi maknanya tidak harus demikian. Sama halnya dengan postmodernisme itu sendiri, apakah berarti sudah melewati batas modernisasi atau tidak modern lagi? Meskipun sebagian mengistilahkan postmodernisme adalah bagian inheren atau turunan dari modernitas, 
sehingga ada korelasi positif antara keduanya. Hanya saja kehadiran postmodernisme sebagai bentuk protes terhadap kompleksitas atas modern (Rirzer, 2005: 51). Melihat beberapa istilah tersebut memang secara rasional susah untuk dijelaskan, apakah pembicaraan "gaya" yang disebut postmodernisme atau 'masa sejarah' yang disebut postmodernitas? Apakah pembicaraan tentang sastra, arsitektur, ataukah filsafat? Apakah ini gejala Barat yakni industrialisasi bangsa yang berkembang? Atau benar-benar global?. "postmodernisme" telah menjadi istilah yang sarat tuduhan: suatu sebutan klise selama tahun 1980an yang dalam banyak hal mencerminkan politik pada dekade waktu itu. Giddens menyebutnya sebagai kesinambungan modernitas dan lebih menyebut periode ini sebagai The Last Modern Era, atau modernitas tinggi (High Modernity). Bagi analisis lain, gejala ini hanyalah perbedaan antara budaya modern sebagai elitis dan tak dapat diakses, dan postmodernisme yang populer dan dapat diakses (Saifudin, 2005: 389-390).

Sebenarnya banyak pengamat sependapat bahwa postmodernisme adalah suatu masa kiamat yang datang perlahan-lahan. Postmodernitas mereka anggap teka teki yang mengganggu. Bagi sebagian orang, postmodernitas adalah budaya "panik", panik seks, panik seni, panik identitas, panik tubuh, panik teori dan sebagainya. Ada juga yang memaknai postmodernitas semata-mata adalah "logika" budaya dari kapitalisme akhir. Apapun istilah yang digunakan, yang menjadi pokok bahwa lanskap budaya dunia (post) modern ini tengah berubah, dan pengalaman mengenai diri kita sendiri dan masyarakat sebagai suatu kesatuan entitas yang stabil semakin problematik dalam pandangan postmodernis.

Sebuah ilustrasi yang memudahkan pemahaman terkait resistensi tradisi terhadap modernitas, kemudian muncul postmodernitas adalah alat transportasi yang disebut bentor (becak motor). Becak selain sebagai salah satu alat transportasi, juga sebagai alat transportasi yang syarat dengan ramah lingkungan karena menggunakan tenaga manusia tanpa bahan bakar. Ini berarti disebut tradisional, sementara motor berarti roda dua yang dikendarai seseorang dengan menggunakan mesin sebagai mode transportasi yang dapat dikategorikan sebagai sesuatu yang modern, lain halnya jika bentor, yaitu sebuah modifikasi, maka perpaduan antara tenaga manusia dan menggunakan mesin. Hal ini menurut penulis sebagai postmodernitas. Bentuk resistensi tradisi terhadap modernitas melahirkan postmodernitas. Tentu kekurangan alat ini, lebih lambat dari dan akan menuju tempat tujuan, mengganggu kelancaran arus lalu lintas di jalan raya, terutama ketika melintas kota tanpa ada pilihan jalan lain. Sisi positif profesi pembecak, selain tenaga manusia adalah mudah dioperasikan, resiko kecelakaan sangat rendah, lebih banyak dan sesuai untuk mengangkut barang-barang belanjaan rumah tangga dari pasar menuju tempat atau rumah pelanggan yang menggunakan jasa becak ini, tidak seperti motor. Artinya perpaduan ojek motor dengan tetap bisa membawa barang belanjaan, dengan 2 penumpang adalah modifikasi becak yang tradisonal, motor yang modern.

Globalisasi sebenarnya sudah menjadi pokok bahasan tersendiri, namun Rowlands juga menyinggung sedikit tentang globalisasi. Dalam dunia multimedia global, bahkan yang lebih penting lagi adalah semua budaya memiliki hak atas representasi yang dapat dipercaya dan akses yang cukup tidak dapat dicapai tanpa perjuangan. Dalam regional conference on globalization di Malaysia tertanggal 4-8 Juli 1997, menyimpulkan bahwa mekanisme pasar sering lebih suka pendaurulangan yang menguntungkan dan stereotype lama dan klise serta mengancam representasi pluralistik (Sardar \& Borin, 2005: 161).

Globalisasi diantarkan dalam tiga kecenderungan umum, diantaranya: pertama, gelombang ekonomi liberalisasi yang dimulai pada tahun 1980-an telah mencapai 
proporsi global setelah jatuhnya komunisme. Pasar menjadi bebas dari pembatasanpembatasan negara, dan kapital kini dapat bergerak melintas batas-batas dengan mudah. Hal ini bisa dilihat bahwa ekonomi mayoritas Negara tengah didominasi oleh pilihan gaya hidup. Sementara produksi digantikan oleh konsumsi sebagai aktivitas ekonomi utama dan privatisasi tengah menjadi norma. Ilustrasi mengartikan globalissi yang mudah bahwa satu produk konsumen, misalnya berupa sebuah komputer, benar-benar bisa diproduksi segmennya secara terpisah di beberapa tempat dan digabungkan di tempat yang lain.

Globalisasi berarti proses meningkatnya kontak antara masyarakat, terutama dalam ruang lingkup ekonomi di seluruh dunia atau bisa dipahami dari lokalisasi-relokalisasi (Saifuidn, 2005: 418); Kedua, Demokrasi liberal secara luas diterima melintas budaya dari Eropa Timur sampai dengan Afrika, bersama asosiasi-asosiasi simbolisnya: penghargaan terhadap HAM, perlindungan lingkungan, kosmopolitanisme, dan yang lain. Pada saat yang sama, kekuasan Negara sendiri telah dilemahkan dihadapan capital global dan batas teritorial menjadi sulit dipertahankan, hukum dan peraturan sulit ditegakkan; ketiga, tren menuju universal budaya barat telah didukung oleh Hollywood, televisi, satelit, musik pop, fashion, dan jaringan informasi global, seperti: CNN, News internastional, dan BBC World Service (Sardar \& Borin, 2005: 162163).

Menurut Nasikun, salah satu guru besar UGM dalam sambutan pengukuhan guru besarnya bahwa globalisasi telah mengakibatkan terjadinya perkembangan "global apatheids", globalisasi "policy making”, peningkatan ketidakadilan global dan nasional (global and domestic inequality), relativisasi hubungan antara individu dan beragam bentuk masyarakat, kebangkitan beragam nilai-nilai "fundamental", perkembangan defisit kesadaran kewarganegaraan (deficit of citizenship), perkembangan defisit demokrasi, perkembangan beragam bentuk gerakan-gerakan sosial dan politik radikal.

Tradisi dan modernitas tidak bisa lepas dari isu-isu dasar tradisi dan modern itu sendiri. Modernise dengan segala kejeniusan imanentalnya telah berhasil meruntuhkan tiang-tiang peradaban tradisionalisme yang begitu takzim mensujudi nilai-nilai etnik, budaya, alam, mistik, dan agama. Tradisi benar-benar terdorong ke bibir marjinalitas sehingga nyaris tidak mampu mempertahankan kesakralannya. Misalnya, merajalelanya gedung-gedung penjebol langit, gelegar mesin-mesin, mobilitas yang sangat cepat, menciutnya batas-batas etnografis, serta terkaparnya doktrin-doktrin agama (Giddens, 2001: v).

Modernisme yang digawangi rasionalisme memandang tradisi sebagai biang keladi terhambatnya transformasi pemikiran dan kritik. Namun disisi lain, rasionalisme juga memicu munculnya kegersangan jiwa, kerontongnya imajinasi, tereduksinya naluri esensial manusia untuk memiliki pelindung supernatural guna melengkapi hakikat kemanusiaannya.

\section{Resistensi Tradisi terhadap Ide-ide Modernitas}

Ide Modernitas yang dikenal berlawanan dengan tradisi, banyak kombinasi modern dan tradisi yang dijumpai dalam lokasilokasi sosial yang konkret. Dalam budayabudaya tradisional, masa lalu dan simbolsimbol dihormati karena memuat dan mengekalkan pegalaman-pengalaman antar generasi. Tradisi adalah bentuk pemaduan monitoring refleksi tindakan dengan organisasi waktu-ruang komunitas, yang menyisipkan pengalaman kontinuitas masa lalu, masa sekarang, dan masa depan. Tradisi tersusun dalam praktek-praktek sosial, dan tidak seluruhnya statis serta tidak begitu menentang terhadap perubahan-perubahan seperti pada konteks yang ada dalam beberapa penanda jarak dan temporal dalam term term perubahan yang bisa memiliki arti (Giddens, 2005: 53-54). 
Bersamaan dengan datangnya modernitas, refleksifitas pun mencapai karakter yang berbeda. Ia diperkenalkan pada basis reproduksi sistem, pemikiran, dan tindakan yang berbasis kembali pada yang lain. Rutinitas tidak memiliki hubungan masa lalu. Sebuah penyelamatan yang dilakukan pada konteks tradisi ditujukan untuk menyerupai hal yang bisa dipertahankan secara prinsipil dalam wilayah pengetahuan. Penggabungan kebiasan diri memang berarti masyarakat modern paling modernis, tetapi tradisi tetap berlanjut untuk memainkan sebuah peranan, meskipun peranan ini tidak signifikan dibanding konsepsi pemaduan antara tradisi dan modernitas di era kontemporer, namun tradisi tetap merupakan sebuah tradisi yang menerima identitasnya hanya dari refleksivitas modern.

Pada akhir abad ke-20, kesadaran klaimklaim tradisional tampak menawarkan kepastian yang disediakan oleh dogma praeksis. Ide ini cenderung persuasif, seolaholah generasinya tidak melihat reflektivitas modernitas menumbangkan alasan yang dipahami sebagai penemuan pengetahaun pasti. Modernitas ditentukan oleh pengetahuan aplikatif, sehingga pada waktu yang sama, tidak yakin bahwa elemen yang diberikan oleh modernitas tidak pernah direvisi.

Di antara ide modernitas adalah globalisasi yang modern artinya modernitas bersifat global. Sebagai deskripsi adalah "kepercayaan" tidak seharusnya selalu seperti apa yang telah dijelaskan oleh para sosiolog, yang menyatakan sebagai sistem yang terkait. Ia harus diganti dengan permulaan yang berkonsentrasi pada analisa kehidupan sosial yang melintasi waktu dan ruang (problematika jarak waktu-ruang). Konsep jarak waktu-ruang menunjukkan perhatian atas hubungan kompleks anatara keterlibatan lokal dengan interaksi yang melintasi jarak. Di era modern, jarak wakturuang jauh lebih tinggi dari pada periode sebelumnya, sehingga antara bentuk-bentuk sosial dan lokal serta kejadian-kejadian menjadi terbentang. Globalisasi dapat juga intensifikasi hubungan sosial yang membatasi lokalits jarak dengan cara melihat kejadian lokal yang dibentuk oleh kejadian dalam beragam waktu dan vice versa. Hal ini merupakan dialektika karena kejadian lokal mungkin begerak dalam arah hubungan yang membentuknya. Transformasi lokal merupakan bagian globalisasi sebagai eksistensi literal hubungan sosial yang melewati waktu dan ruang.

Salah seorang postmodernis Jean Baudrilliard, Dia memahami postmodernitas sebagai fase sejaranh yang sangat memalukan. Dia anggap masyarakat postmodern dipandang menutup kesempatan yang telah dibuka karena berakhirnya modernisme. Alhasil, Baudrilliard menawarkan ide-ide dasar tentang sifat masyarakat dalam dunia modern. Pertama, teori yang biasanya berorientasi pada penegasan kebenaran, sedangan Baudrilliard kebenaran itu tidak ada; Kedua, ia menolak yang nyata (the real), pendekatan dia benarbenar "teori anti sosial" dalam batas tertentu, dia menolak berakhirnya teori sosial menurut pemikiran tradisional untuk menggambarkan yang nyata; Ketiga, mustahil memprediksi apa yang akan terjadi dengan kesimpulan bahwa teori tidak bisa lebih dari pada pengharapan bahwa realitas cukup naif untuk jatuh ke dalamnya. Bahkan Baudrilliard mendorong teori pada titik extream, pataphysic adalah satu-satunya cara melawan yang lebih nyata dari sistem nyata (hiperrealitas) dimana manusia hidup. Jadi baginya, saya tidak tertarik pada realisme...buku-buku saya adalah skenarioskenario. Saya menghabiskan sedikit demi sedikit akhir sesuatu. .. ini adalah perminan, sebuah provokasi. Bukan untuk menghentikan secara total segala sesuatu, tetapi sebaliknya akan menciptakan segala sesuatu mulai lagi (Ritzer, 2005: 234-235).

\section{Resistensi Tradisi terhadap Nilai-nilai Institusi}

Sebelum berbicara lebih dalam mengenai teori-teori untuk menemukan satu institusi 
yang dominan dalam masyarakat modern, perlu dikkemukakan apakah institusi-institusi itu kapitalistik atau industrial?. Hal ini perlu disampaikan sebab dalam waktu yang bersamaan didasarkan pada premis-premis yang salah karena masing-masing mencerminkan

industrialisme. reduksionisme-

industrialisme harus dilihat sebagai kelompok orang-orang anisasional yang berbeda atau dimensi-dimensi yang terlingkup dalam institusi-institusi modern.

Kapitalisme merupakan sistem reproduksi komoditi yang dipusatkan pada hubungan pemilik modal pribadi dan upah buruh minimum. Perushaan kapitalisme tergantung pada produksi pasar-pasar kompetitif, harga yang menjadi tanda-tanda bagi investor, produsen-produsen, dan konsumenkonsumen yang sejenis. Adapun karakter utama industrialisme adalah penggunaan sumber-sumber tak bergerak kekuatan materi dalam proses produksi.

Ilustrasi yang mudah, mesin bisa didefinisikan sebagai barang, otak manusia yang mengemban tugas-tugas dengan memberikan sumber-sumber kekuatan sebagai alat operasionalnya. Pembicaraan industrialisme tentu mencakup organisasi sosial reguler produktif dalam memasukkan aktivitas manusia, mesin-mesin, dan pemasukan-pemasukan, pengeluaranpengeluaran barang mentah dan barang jadi. Tentu industrialisasi tidak dipahami sempit, karena asal muasalnya dalam revolusi industri menuntut manusia untuk bekerja keras. Termasuk dalam gagasan industrialisme adalah mengaplikasikan tempat-tempat teknologi tinggi, dimana listrik hanya menjadi sumber kekuatan dan mikrosirkuit elektronik hanya menjadi alatalat mekanik. Indutrialisme tidak hanya mempengaruhi tempat kerja, melainkan juga transportasi, komunikasi, dan kehidupan domestik. (Giddens, 2001: 80-82).

Anthony Giddens (1990) menggambarkan dunia modern sebagai sebuah "lokomotif". Kesan yang ditimbulkan dari lokomotif adalah sesuatu yang bergerak sejalan dengan waktu dan ruang fisik, tetapi perumpamaan tentang lokomotif, tidak pas dengan penekanan Giddens terhadap kekuasaan agen, kesan yang ditimbulkan lokomotif sepertinya sesuai dengan mekanisme modern yang jauh lebih berkuasa dari agen yang mengendalikannya. Dalam analisisnya mengenai modernitas, Giddens menitikberatkan perhatiannya pada nationstate dan menentukan modernitas dalam istilah empat instansi dasar. Pertama, kapitalisme yang dikarakteristikkan secara familier dengan produksi komoditas, kepemilikan privat, upah buruh tanpa kepemilikan, dan sebuah sistem kelas yang berasal dari karakteristik tersebut; Kedua, industrialisme yang melibatkan sumbersumber tenaga mati dan mesin untuk memproduksi barang, industrialisme tidak terbatas pada tempat kerja, dan berpengaruh pada kesatuan penghaturan lain, semisal transportasi, komunikasi, dan kehidupan domestik; Ketiga, kapasitas-kapasitas pengamatan, bagi Giddens adalah merujuk pada suatu pengawasan yang keras terhadap aktivitas-aktivitas populasi subjek dalam bidang politik; Keempat, kekuatan militer, atau kontrol atas tujuan-tujuan kekerasan, termasuk industrialisme perang. Dengan demikian, dari empat institusi yang ditawarkan Giddens tersebut, ada sebuah esensi bahwa pemisahan waktu dan ruang mutlak dibutuhkan, dalam masyarakat pramodern, waktu selalu dikaitkan dengan ruang. Sementara modernisasi, waktu distandarisasi. Padahal ruang bagi pramodern, kebanyakan ditentukan oleh kehadiran fisik, artinya ruang yang dilokalisasi dengan modernitas, ruang semakin terpecah dari tempatnya (Ritzer, 2005: 2005: 240-249).

Berikut ciri institusional yang spesifik dalam masyarakat kapitalisme. Pertama, aturan ekonominya meliputi karakteristikkarakteristik tertentu dan ekspansi perusahaan kapitalis yang kompetitif cenderung mengartikan inovasi teknologi secara konstan dan pervasif; Kedua, ekonomi agak berbeda dan terisolasi dari arena sosial 
lain, khususnya institusi politik dengan memberikan inovasi tingkat tinggi dalam bidang ekonomi. Hubungan ekonomi memiliki kekuasaan-kekuasaan yang dapat dipertimbangkan pada institusi-institusi lain; ketiga, isolasi politik dan ekonomi dibangun pada keutamaan harta milik pribadi atas alatalat reproduksi. Kepemilikan modal secara langsung berkaitan dengan fenomena komoditi upah buruh minimum dalam sistem kelas, kendati rasa kuat tidak ditentukan oleh kepercayaan atas akumulasi modal yang kontrolnya belum sempurna; Keempat, dimensi institusional yang harus dibedakan yaitu kontrol alat kekejaman. Kekuatankekuatan militer selalu menjadi ciri central peradaban pra modern, namun sentral politik dalam peradaban itu tidak pernah memperoleh dukungan militer pemerintah bergantung pada aliansi-aliansi dengan pangan lokal.

Persoalannya, mengapa masyarakat kapitalis juga disebut masyarakat? Dengan memberikan karakteristik ekspansifnya, kehidupan ekonomi kapitalis hanya terdapat dalam beberapa bidang yang dibatasi oleh sistem-sistem sosial spesifik. Jadi masyarakat kapitalis tetaplah kapitalis, karena ia merupakan Negara. Karakter Negara dalam substansial harus dijelaskan dan dinalisis secara terpisah dari pembahasan dunia kapitalisme ataupun industrialisme. Pada umumnya, sistem adminsitatif negara kapitalis dan modern harus dimaknai melalui kontrol koordinatif terhadap arena teritorial terbatas yang dicapainya. Administrasi negara ini bergantug pada perkembangan pengawasan kapasitas-kapasitas pengawasan yang melebihi peradaban-peradaban tradisional. Alat-alat pengawasan menentukan dimensi institusional ketiga yang dihubungkan dengan kapitalis.

Bagi Marx, kapitalisme memainkan peran terbesar dalam menganagkat kehidupan sosial modern dari institusi-institusi tradisional. Jika kapitalisme merupakan elemen besar intitusional yang mempromosikan akselerasi dan ekspansi institusi-institusi modern, maka yang lain berkembang menjadi Negara. Negara-negara dan sistemnya tidak bisa dijelaskan dalam term-term bangkitnya perusahaan kapitali. Melihat keempat dimensi institusional ini, terletak pada tiga sumber dinamisme modernitas yang harus dibedakan terlebih dahulu: jarak ruang waktu, ketakterimpangan dan refletivitas. Tanpa semua itu, pemilihan modernits dari tradisionalitas tidak akan pernah tercapai dalam cara yang radikal, cepat dan melintas tingkatan dunia yng luas. Semuanya terlingkup dan dikondisikan oleh dimensi-dimensi institusional modernitas (Giddens, 2001: 90).

\section{Resistensi Tradisi terhadap Mekanisme Modern}

Ketika berbicara tentang modernitas, maka pada saat yang sama, sebenarnya menunjuk pada transformasi institusional yang memiliki akar-akarnya di Barat sejauhmana modernitas tetap eksis di Barat? Dalam menjawab soal ini, harus dipertimbangkan dua ciri modernitas yang terpisah-pisah dalam klasifikasi institusional, dua organisasi yaitu negara-negara dan produksi kapitalis sistemik. Bentuk-bentuk sosial yang tradisional telah menggambarkan kekuatan ini melalui pemeliharaan otonom diluar kecenderungan-kecenderungan perkmbangan global.

Dewasa ini, proses perubahan sosial, budaya, dan politik sulit untuk dilepaskan dari perkembangan dinamika global. Globlisasi ekonomi dan budaya berpengaruh pada penciptaan kultur yang homogen (tradisional) yang mengarah pada penyeragaman selera, konsumsi, gaya hidup, nilai, identitas, dan kepentingan individu. Sebagai produk modernitas, globalisasi tidak hanya memperkenalkan masyarakat di pelosok dunia akan kemajuan dan kecanggihan sains dan teknologi serta prestasi lain seperti instumen dan institusi modern hasil capaian peradaban Barat sebagai dimensi institusional modernitas, tetapi juga mengintrodusir dimensi budaya modernitas, seperti nilai-nilai demokrasi, pluralisme, toleransi, dan Hak Asasi 
Manusia. Meskipun beberapa negara yang kurang memiliki tradisi demokrasi menolak proses globalisasi ini, namun demikian, seperti ditunjukkan Huntington (1991: 5), hampir tidak ada negara yang tidak mendukung demokrasi sebagai sistem yang kurang lebih ideal guna mengatu kehidupan masyarakat. Sayangnya, di tengah sambutan gegap gempita terhadap proses demokratisasi, ada paradoks yang menyertai perkembangan global ini, yaitu semakin terdegradasinya kualitas demokrasi negaranegara di dunia. Paradoks ini misalnya bahwa kemajuan teknologi informasi dan komunikasi di satu sisi memberi kemudahan bagi publik dalam mengakses informasi dan kounikasi, pada sisi lain memberi kemudahan bagi publik dalam mengakses informasi, mengembangkan segenap potensinya serta tuntutan perjuangan hidupnya, tapi di sisi lain, globalisasi telah menjadi instrumen negara-negara industri maju dan kekuatan elit minoritas pemilik modal guna melakukan hegemoni dan dominasinya atas kehidupan sosial, ekonomi dan budaya masyarakat. Lain halnya prinsip ngango dalam negara, bahwa bagi dia, kedaulatan ada di tangan rakyat, sematamata buka karena di Indonesia telah terwakili oleh para legislatif, akan tetapi bagaimana mampu membuat rakyat sebagai pemegang daulat betul-betul dapat membuat kebijakan versi rakyat, bukan versi rezim yang berkuasa. Jadi modern bagi Ngango adalah ketika sebuah kekuatan lokal dapat eksis, bahkan tetap mewarnai dalam dinamika kehidupan yang lebih publik.

Kekuatan kapitalisme global dan perusahaan-perusahaan transnasional bergerak melampaui batas-batas teritorial suatu negara guna melakukan ekspansi ekonomi di berbagai pelosok dunia, yang mana pada level tertentu telah membawa implikasi makin melemahnya posisi kekuatan ekonomi lokal. Dengan demikian, globalisasi juga mengarah pada penguasaan ekonomi di tangan sekelompok kecil pemilik modal, dan akhirnya menuju pada proses homogenisasi. Dalam perspektif cultural studies, hegemoni ini tampak dalam penciptaan pola hidup konsumeristik dan pop culture, yang memposisikan manusia sebagai objek distribusi produk belaka. Globalisasi telah membuat dunia makin terbuka, dan melahirkan aneka tuntutan perluasan partisipasi dan pemberdayaan rakyat yang lebih besar. Fenomena ini juga diiringi oleh munculnya berbagai bentuk penegasan kembali identitas-identitas komunal masyarakat. Adanya tuntutan pengakuan atas identitas komunal dan hak budaya lokal sekaligus membuktikan, ada resistensi atas kecenderungan peminggiran, dominasi dan homogenisasi global.

Akhirnya, mengutip ungkapan David Held dalam Democracy and The Global Order: From the Modern State to Cosmopolitan Governance (1995: 193), bahwa otonomi masyarakat hanya bisa dicapai melalui dua cara. Pertama, pengakuan atas Hak Asasi Manusia yang diperluas mencakup hak sosial, ekonomi dan budaya. Kedua, adanya keterlibatan masyarakat dalam proses pengambilan kebijakan yang tidak hanya dibatasi pada institusi-institusi pemerintah, tetapi diperlebar sampai menyentuh institusiinstitusi dan proses sosial-ekonomi.

Dari uraian tersebut, Michael Rowland masih kaku terhadap apa yang mendasari antara tradisi dan modernitas yang keduanya tidak bisa saling menerima satu dengan yang lain, sementara dalam kajian lebih luas, justru hampir tidak dapat disekat-sekat antara batas keduanya. Penulis justru melihat bahwa ada dunia baru pasca modernitas, yang tidak kembali pada ranah tradisi atau klasik lagi, hal ini tentu dilihat sebagai sebuah keniscayaan oleh hadirnya produkproduk budaya yang berkembang saat ini, manusia dipaksa aktif untuk mengikutinya, dan sebagai balasannya mereka mendapatkan kepuasan dan kebanggan meskipun sebenarnya adalah semu dan kesadaran palsu. Manusia dijebak dan dikurung dalam lingkungan pemujaan sehingga menjadikan mereka tidak kritis, lemah dan rentan terhadap eksploitasi. Pada saat inilah konsep modernitas yang membelenggu seseorang tidak lagi kritis, maka fase postmodernitas 
lahir sebagai kolaborasi antara konsep tradisi dan modernitas, meskipun kemudian dalam konteks operasional institusi mereka yang menggunakan konsep posmodernitas tidak selamanya bisa diterima di tengah-tengah mereka hidup dan bersosial, selain ada wilayah-wilayah yang memang belum menerima konsep postmodernitas, di sisi lain masyarakat belum siap menerima sebuah dinamika kehidupan yang selalu berubah dan berkembang.

Pada saat yang sama, ada anggapan bahwa jika seseorang mengkritik modernitas berarti mereka tidak menerima hal-hal yang baru. Artinya sangat sulit untuk keluar dari segala hal yang berkembang, apalagi dalam konteks sekarang ini, diera digitalisasi. Justru diperlukan iklim yang terbuka dan bebas mengkonsumsi apapun bagi yang bersangkutan. Postmodernitas lahir untuk mewadahi dan menjembatani kepentingan yang tidak siap meninggalkan sebuah tradisi dan tetap menerima modernitas dengan "baju baru” yang penulis sebut sebagai posmodernitas. Dengan demikian, apapun yang ditimbulkan atas modernitas, baik yang materi maupun immateri bahkan yang berupa subkultur dari budaya tandingan yang bersifat resisten dan konstruktif tetap diterima sebagai sebuah keniscayaan, namun diperlukan wahana baru jika memungkinkan karena pada dasarknya posmodernitas lahir atas kurang respeknya tradisi terhadap modernitas. Sebaliknya juga berlaku, atas sempurnanya modernitas yang mampu memberikan ruang yang bebas terhadap zamannya namun menghilangkan ruh atau susbtansi dari sebuah tradisionalitas.

\section{Simpulan}

Dalam masyarakat industrialis, kita harus menerima dan memasuki periode modernitas tinggi yang melepaskan ikatannya dari penentraan tradisi dan memilih menambatkan diri pada posisi yang menguntungkan dalam dominasi Barat. Memang pada awalnya, modernitas mencari kepastian untuk mengganti dogma atau tatanan fundamen yang dibangun sebelunya, namun modernitas secara efektif berhasil melebarkan institusional kebimbangan.

Modernitas merupakan globalisasi yang melekat pada fenomena konsekuensikonsekuensi yang berkombinasi dengan sirkularitas karakter refleksinya dalam membentuk kejadian-kejadian resiko dan bahaya yang mengukuhkan karakter alur hidup. Tendensi-tendensi globalisasi modernitas secara simultan merupakan ekstremitas dan intensitas yang dapat menghubungkan individu-individu pada sistem berkala besar sebagai bagian dialektika kompleks perubahan pilar-pilar lokal dan global. Modernitas terorientasi sebagai masa depan yang memiliki bentuk counter faktual, sementara postmodern mungkin berupa tiga kumpulan faktor, pertama menunjuk pada penggarisbawahan alam dinamis modernitas, jika institusiinstitusi modern sutau saat transidentalkan, maka ia akan turut berubah secara fundamental.

Jadi sebutan "modern" karena adanya sebutan "tradisional" atau sebutan "global" karena adanya sebutan "lokal". Persoalannya, mungkinkah ada fase kehidupan diantara "lokal" dan "global", ataukah diantara "tradisional" dan "modern”? untuk itu dalam kesimpulan penulis, bahwa negara yang sangat mempunyai kepentingan dan andil dalam menentukan arah masa depan modern ini, atau orang pada dewasa ini lebih cenderung mempertahankan tradisi atau lokal yang masih dianggap memberi keuntungan melalui pemeliharaan dan pelestarian tradisi atau global, disamping juga menerima globalisasi dan modernitas sebagai keseimbangan antara perkembangan dinamika sosial (postmodernitas).

\section{Daftar Pustaka}

Adnani, Kamila. (2016). Resistensi Perempuan Terhadap Tradisi-Tradisi Di PesantrenAnalisis Wacana Kritis Terhadap Novel Perempuan Berkalung Sorban, Jurnal Pascasarjana UGM Kawsitara Volume 6 No. 2, 17 Agustus 2016. 
Fedyani, A. Saifudin. (2005). Antropologi Kontemporer: Suatu pengantar Kritis mengenai Paradigma, Jakarta: Prenada Media.

Giddens, Anthony. (2001). Tumbal Modernitas Ambruknya Pilar-pilar Keimanan, Penerj. M. Yamin, Yogyakarta: IRCiSoD.

Held, David. (1995). Democracy and The Global Order: From the Modern State to Cosmopolitan Governance, Calivornia: Stanford Universiy Press.

Huntington, SP. (1991). Gelombang Demokratisasi Ketiga, Jakarta: PT. Intermasa.

May, Abdurrachman. (2013). Resistensi Aliran Salafi Terhadap Islam Tradisional Di Lombok Barat, Nusa Tenggara Barat, Jurnal Media Bina Ilmiah: Volume 7, No. 6, Desember 2013

Miller, Daniel. (1995). Worlds Apart: Modernity Through the Prism of the Local, New York: Routledge.

Mulyanto, Dede.(2016). Karl Marx, Antropologhits (Resensi Buku),Journal: UMBARA : Indonesian Journal of Anthropology, Volume 1 (1) Juli 2016.

Ritzer, George. (2005). Teori Sosial Postmodernpenerjemah Muhammad Taufik, Yogyakarta: Kreasi Wacana.

Sardar, Z \& Van Loon, Borin. (2005). Seri Mengenal dan Memahami Cultural Stidies, Batam: Scientific Press.

Scoot, James C. (1981). Moral Ekonomi PetaniPergolakan dan Subsistensi di Asia Tenggara-penerjemah Hasan Basri, Jakarta: LP3ES.

Rowlands, Michael. (1995). Inconsistent Temporalities in a Nation-Space dalam Worlds Apart: Modernity Through the Prism of the Local, New York: Routledge. 